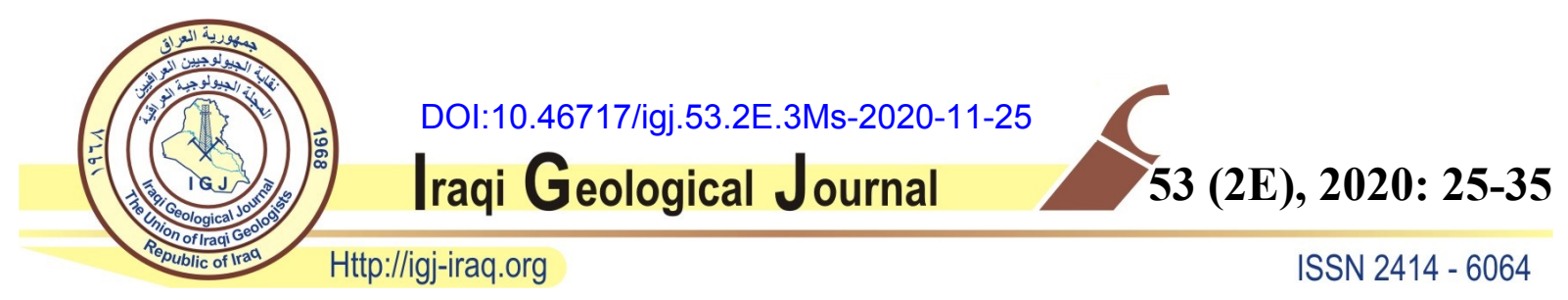

\title{
GEOEDUCATIONAL AND GEOTOURISM VALUES OF AGGREGATE QUARRIES, MISSAN, SOUTHEASTERN IRAQ
}

\author{
Riaed S. Al Siaede \\ College of Engineering, University of Missan, Missan, Iraq \\ Email:Dr.ra.iraq@uomisan.edu.iq \\ Received: 13 March 2020; accepted: 28 September 2020
}

\begin{abstract}
The geoeducation and geotourism potential capabilities were quantitatively estimated in nine quarries locations in eastern Missan, SE Iraq. A quantitative approach is used to compute the scientific, educational, functional, and touristic categorises values for each quarry. categorised values were weighted for three types of audiences: university students, school pupils, and tourists then, the previous geoscientific studies about quarries areas were searches of different geoscience branches and registered. The results show that geoeducation values are greater than geotourism ones in all quarry sites. All quarries show high weight for the education values while the geotourism values are affected by functional infrastructure in each site. The diversity of scientific values of each site are also studied where the petroleum and hydrological activities increased the geoeducation weight of the specific site and supplied more geological knowledge.
\end{abstract}

Keywords: University; Students; School pupil; Tourists; Geoscience knowledge; UNESCO

\section{INTRODUCTION}

Geotourism, or tourism related to geological sites and features, including geomorphological sites and landscapes, relatively it is a new phenomenon that resulted from a subgroup of geology and tourism. Geotourism charter, which was developed by the National Geographical Society (NGC) is focused on the geoeducation to improve the relation between the visitors and hosts in the geoeducation and geotourism sites, "Interactive interpretation engages both visitors and hosts in learning about the place. Encourage residents to show off the natural and cultural heritage of their communities, so that tourists gain a richer experience, and residents develop pride in their locales" (Herzog et al., 2008 and Errami et al., 2009). Awadh (2016) determined the outstanding values of the Sawa Lake, western Iraq as a world natural heritage.

Strba et al. (2020) focused on the economic and environmental benefits of the geotourism and find that the geotourism related activities will contribute to promoting the protection of 
geosites in protected areas. The geosites evaluation has been developing since the 1990s, in three main domains: within the context of Environmental Impact Assessment (EIA) procedures, (for the elaboration of geographic knowledge on the geomorphological heritage in the context of land planning; and finally, in the context of geoheritage promotion (geotourism and cultural heritage in a broad sense). Tomić, and Božić, (2014) developed the Geosites Assessment Model (GAM) used in the assessment of the three aforementioned geosites in Lazer Canyon is Serbia, and concluded that the tourists in the assessment process have a decisive role on model final results. Geoeducation is an important prerequisite for any region to be a geopark according to UNESCO demands "Education at all levels is at the core of the UNESCO global Geopark concept. From university researchers to local community groups, UNESCO Global Geoparks encourage awareness of the planet story as read in the rocks, landscape, and ongoing geological processes" (Henriques and Brilha, 2017). The outdoor studies and the geosite visits are vital requirements to develop student practical skills, Weather, geoscience university departments students, or school pupils (Gajek et al., 2019; Tipon et al., 2016 and Tetik, 2016).

Aggregate quarries and surface mining industry make a giant leaps expansion in the last decade through the boom concrete constructions and road pavements in Maissan. The quarries can be considered as an artificial outcrop, where the rock successions, minerals, fossils and sedimentary structures are exposed for the visitors, and samples can take at any depth of quarry section (Collis and Smith, 2001; Sinclair, 2012). Gajeck et al. (2019) developed a quantitative approach to evaluate the scientific, educational, functional, and touristic validity of the quarries for three audience groups, university students, school pupils and tourists. This assessment procedure was used in recent study to assess the validity of the study area quarries as educational and tourism purposes. In this study, Gajeck procedure is used to evaluate the geoeducational and getourism values of nine quarry sites located at east Missan governorate area (Southeastern Iraq) were estimated, the scores of three audience categorises (university students, school pupils and tourists) are weighted. Finally, a comparison between the geoeducation and geotourism capabilities of current circumstances.

\section{STUDY AREA}

Eastern Missan governorate area (Fig.1) is about $46 \%$ percent of the province area. It is characterized by beautiful nature; many local and foreign tourists visit it during year (Fig. 2). This area also has a rich society diversity including agriculture villages, Bedouin communities and sheep herders with presence of oil sites, groundwater wells and aggregate quarries. The quarries are active and non-active clay, sand, gravel, and subbase quarries (Fig. 3). Nine quarries were selected in different parts of the area (Table. 1) to cover the requirements of the 
current study. The study area is covered with Zagros foothill deposits like, alluvial fan, dunes, and colluvial deposits which derived from the mountains lies to the East North direction across Iraqi Iranian border (Ameen, 2005) (Fig. 4). The lithology and geological ages of the outcropped formations are represented in Table.1, while the geological succession represented in Table 2 (Al-Siaede, 2019). The geoeducational and geotourism importance of this area are resulting from the topography, geological diversity of the sediments and the sedimentary structures. Also, the area includes a wide range of rare wild animals and natural plants that grow in this environment. The area is characterized by tourist potential, especially for the families of the province or from the nearby provinces, although there are no tourist centers in it. Many graduate students and researchers from geological, geographical, biology and oil engineering disciplines have completed their studies on the natural resources and phenomena of the region.

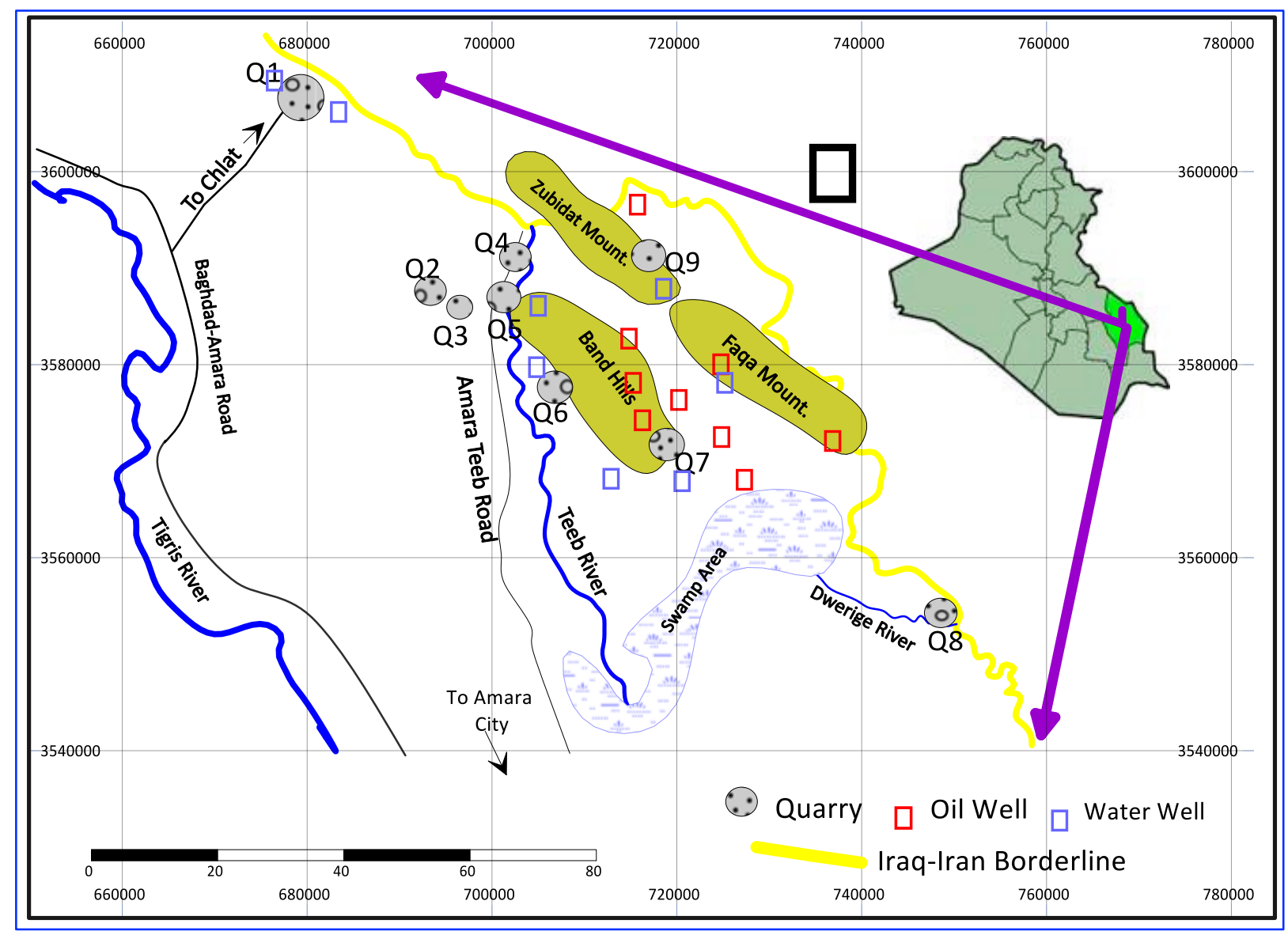

Fig. 1. The locations map of the study area sites

\section{MATERIALS AND METHODS}

Several geoheritage evaluation techniques were reviewed such as Štrba (2015); Tomić, and Božić (2014). Gajeck et al. (2019) technique was followed in this study because it is a quantitative approach dedicated to the evaluation of the areas of the quarries in addition to focusing on the geoaeducation and geotourism topics. 
Table 1. The lithology and coordinates of the selected quarries in the study area

\begin{tabular}{|c|c|c|c|}
\hline Location & UTM Coordinates (D M S) & Local Name & Notes \\
\hline Q1 & $\begin{array}{c}680127,3606579 \\
(323547 \mathrm{~N}, 465552 \mathrm{E})\end{array}$ & Chlat & $\begin{array}{l}\text { Gravel, sand and subbase Quarries, water wells and } \\
\text { many sedimentary and structural features. }\end{array}$ \\
\hline Q2 & $\begin{array}{c}693626,3587005 \\
(332409 \mathrm{~N}, 470339 \mathrm{E}) \\
\end{array}$ & \multirow{2}{*}{ Manzilyea } & \multirow{2}{*}{$\begin{array}{l}\text { Area of seismic activity located on blinding faulting } \\
\text { system. Sand dunes and water wells are located } \\
\text { with many sedimentary structures. }\end{array}$} \\
\hline Q3 & $\begin{array}{c}698432,3585511 \\
(322317 \mathrm{~N}, 470623 \mathrm{E})\end{array}$ & & \\
\hline Q4 & $\begin{array}{c}704405,3591846 \\
(322509 \mathrm{~N}, 471006 \mathrm{E})\end{array}$ & \multirow{2}{*}{ Teeb } & \multirow{2}{*}{$\begin{array}{l}\text { These quarries are near Teeb river on the area, area } \\
\text { included many petroleum drilling and water wells, } \\
\text { geologically area rich with different kinds of } \\
\text { sedimentary rocks. }\end{array}$} \\
\hline Q5 & $\begin{array}{c}703304,3588063 \\
(322639 \mathrm{~N}, 471033 \mathrm{E})\end{array}$ & & \\
\hline Q6 & $\begin{array}{c}707696,3576179 \\
(321830 \mathrm{~N}, 471033 \mathrm{E}) \\
\end{array}$ & \multirow{2}{*}{ Band } & \multirow{2}{*}{ Band hills is beautiful area with many heritage sites } \\
\hline Q7 & $\begin{array}{c}717921,3574636 \\
(321332 \mathrm{~N}, 471819 \mathrm{E})\end{array}$ & & \\
\hline Q8 & $\begin{array}{c}749158,3551396 \\
(320417 \mathrm{~N}, 473820 \mathrm{E})\end{array}$ & Dwerige & $\begin{array}{l}\text { Cross Bedding sedimentary structure. Outcrop of } \\
\text { silt sand and gravel layers. }\end{array}$ \\
\hline Q9 & $\begin{array}{c}716481,3593523 \\
(322236 \mathrm{~N}, 471920 \mathrm{E})\end{array}$ & Zubidat & Mudstone, Siltstone, and sandstone outcrop \\
\hline
\end{tabular}

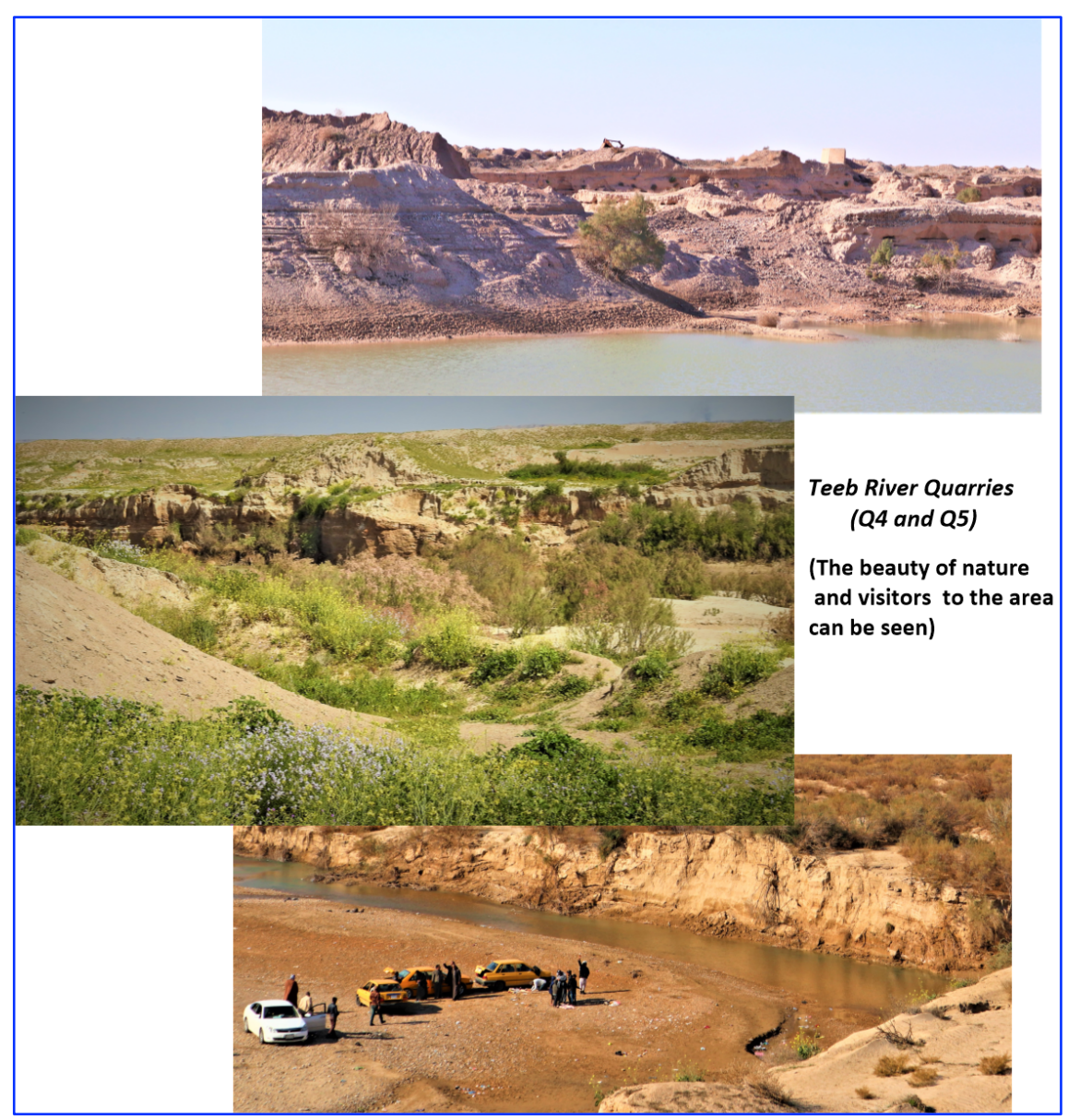

Fig. 2. Quarries of the east Missan Area 


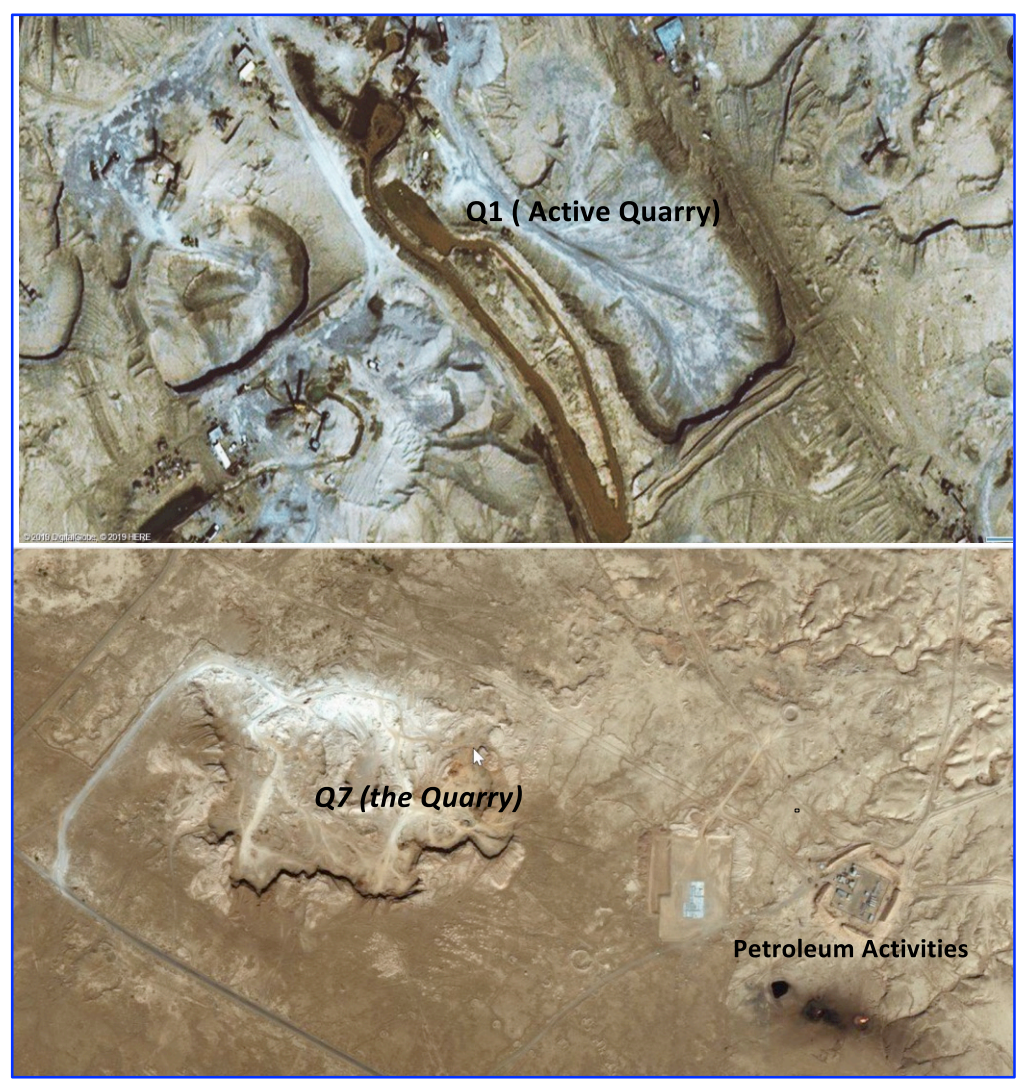

Fig. 3. Satellite images (Digital Globe Images, Scale 1:100000) of Q1 and Q7 Quarries

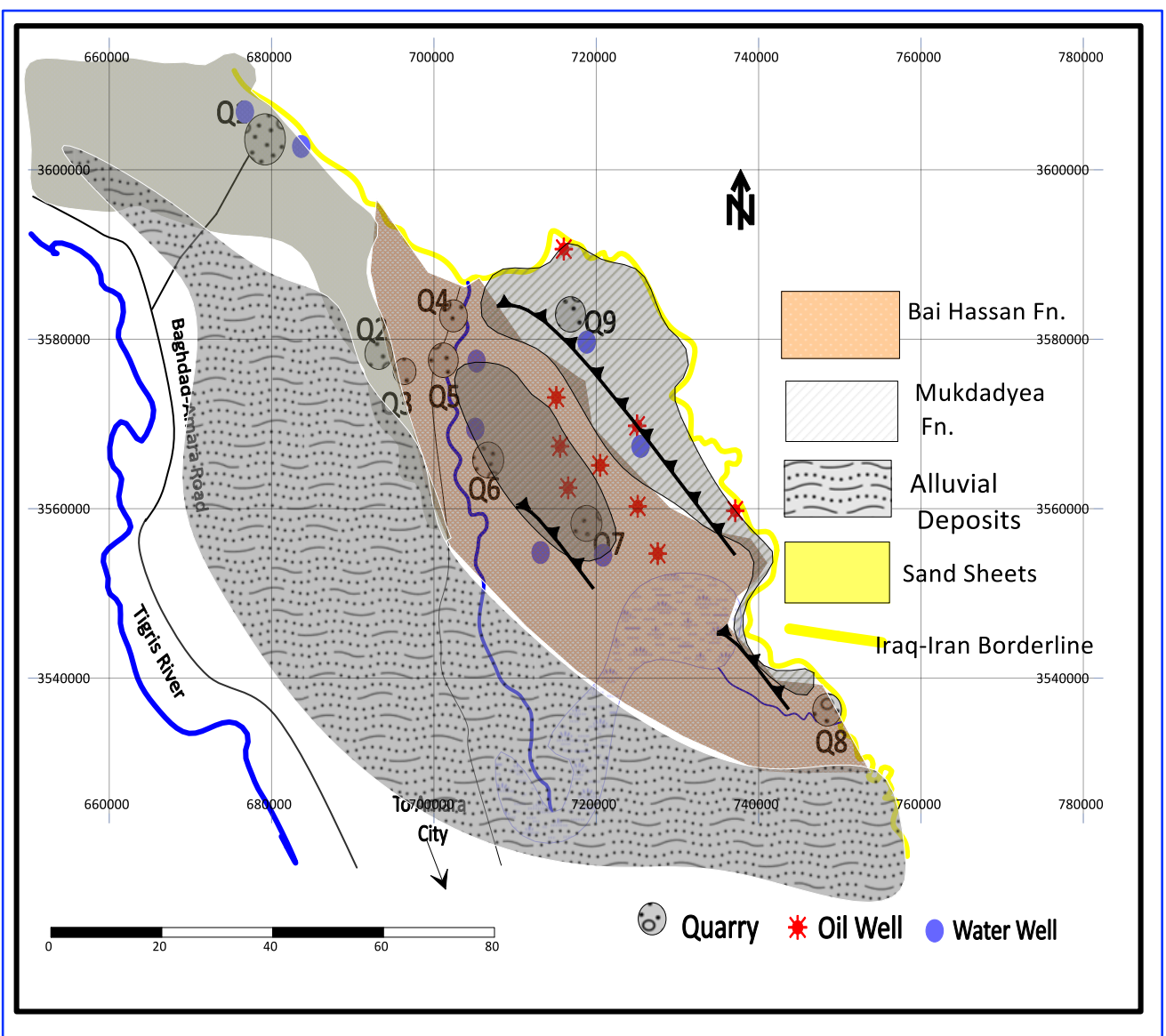

Fig. 4. Geological map of the study area (modified from GEOSURV, 2000) 
Table 2. Lithology and geological ages of the study rock formations (Aqrawi, et al. 2010)

\begin{tabular}{|c|c|c|}
\hline Formation & Geological age & Lithology \\
\hline $\begin{array}{l}\text { Quaternary } \\
\text { Deposits }\end{array}$ & Recent & $\begin{array}{l}\text { Sand dunes, Sand sheets alluvial and colluvial deposits comprised } \\
\text { mainly of gravel, pebble, sand, silt and clay. Sand dunes and river } \\
\text { terraces are formed. }\end{array}$ \\
\hline Bai Hassan & Late Pliocene & Mudstone and conglomerates with some sandstones and siltstones \\
\hline Mukdadiya & $\begin{array}{l}\text { Upper Miocene- } \\
\text { lower Pliocene }\end{array}$ & $\begin{array}{l}\text { Thick massive sandstones beds changed to pebbly with thin } \\
\text { conglomerates. The lithology changed in upper part to light brown } \\
\text { claystone with few sandstones and lenses of pebbles. }\end{array}$ \\
\hline Injana & $\begin{array}{l}\text { Early to Late } \\
\text { Miocene }\end{array}$ & $\begin{array}{l}\text { Marls and siltstones with beds of sandstones. Freshwater limestones } \\
\text { and lacustrine clay and bentonite are occasionally occurred. }\end{array}$ \\
\hline
\end{tabular}

This technique relies on estimate four criteria in each quarry (Table 3), scientific, educational, functional, and touristic. The criterial topics were evaluated on five elements, with a maximum score of 10 (40 for the total score). To evaluate the effect of these criteria on the visitors for each quarry site, the quantitative values are generated in Table 3 are multiplying them by weighting factors (Table 4A). The focus has been on three types of audiences, university students, school pupils and tourists. The results were analysed by comparing with a classes interval for the final scores of the quarries and for the audiences (Table 4B). The selected Quarries in this study are quantitatively evaluated by new method depends mainly on Gajeck et al. (2019) scoring value and weight factors tables (Table 3 and 4A) as following:

1. The study area was surveyed by remote sensing images, previews maps, and field visits to select the suitable quarries for geoeducation and geotourism purposes. The main factors for quarries selection controlling are, security, scientific importance, validity of different geological activation in the area and the distance from the main paved roads.

2. Scientific, educational, functional and tourism scores are computed with maximum 10 points for each part (Table 3 ). The results are multiplying by weight factors to find the group audience values for three audience groups, university students, school pupils, and tourists (Table 4A).

3. Previous geoscience studies (M. Sc, Ph. D thesis and papers were published in scientific journals) on the East Missan region have been revised to determine the geoscience information available on each quarry sites (Fig. 5).

4. Finally, the results of each quarry values are represented in Table 4. The scientific and educational score marks are collected to represent the geoeducation score value, the functional and tourism scores marks collected to represent the geotourism scores. 


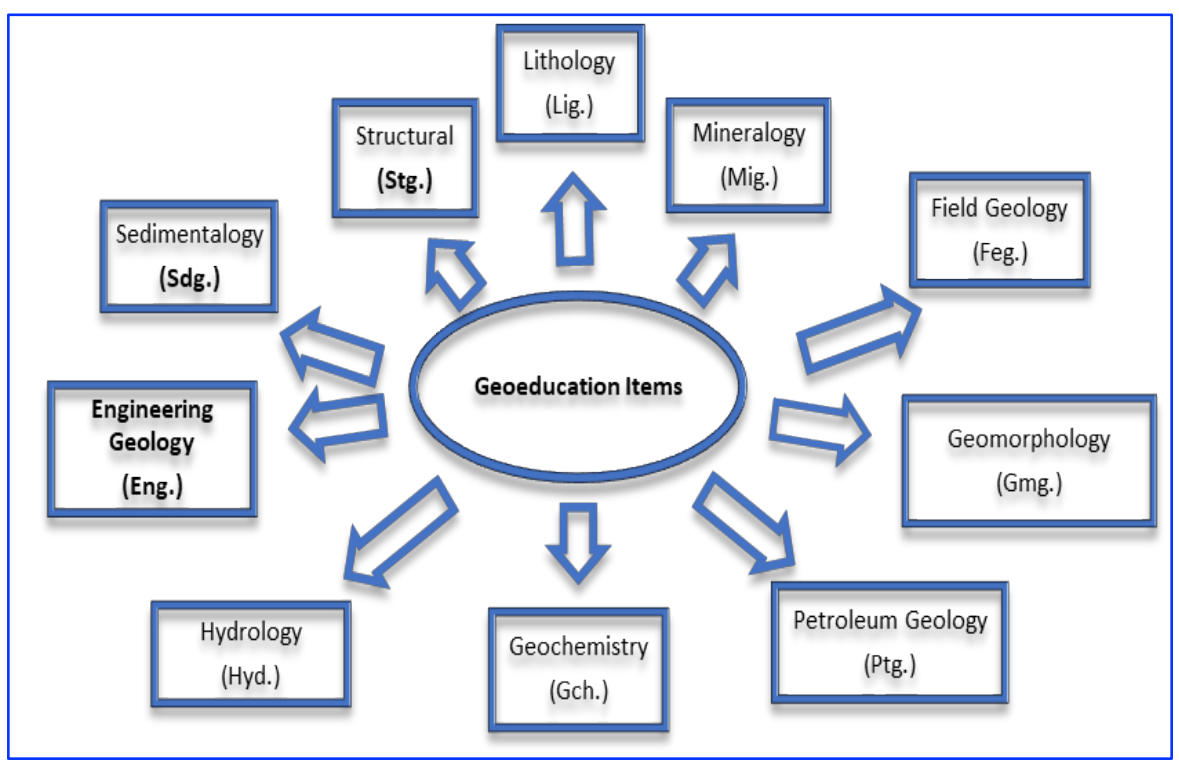

Fig. 5. Geoscience specialization taken in the study

Table 3. Quantitative scores for quarries assessment (modified from Gajeck et al., 2019)

\begin{tabular}{|c|c|c|c|}
\hline Criteria & Low value 0 pts & Medium value 1 pts & High value 2pts \\
\hline \multicolumn{4}{|c|}{ Scientific } \\
\hline Representative & Lacks outcrop & Incomplete outcrop & Typical outcrop \\
\hline Rarity & $>3$ similar sites in the region & One of 3 sites in the region & Only site in the region \\
\hline Scientific knowledge & Lack in scientific literature & 3-5 publications & $>5$ publications \\
\hline Geological Diversity & One feature & $2-3$ features & $>3$ features \\
\hline Extensiveness & $<10 \mathrm{~m}$ & 10 to $20 \mathrm{~m}$ & $>20 \mathrm{~m}$ \\
\hline \multicolumn{4}{|c|}{ Educational } \\
\hline Observation condition & $\begin{array}{l}\text { high vegetations and } \\
\text { weathered materials cover }\end{array}$ & $\begin{array}{l}\text { Partially vegetations and } \\
\text { weathered materials cover }\end{array}$ & $\begin{array}{l}\text { No vegetations and weathered } \\
\text { materials cover }\end{array}$ \\
\hline Education tools & Lack of products & $1-2$ products & More than 2 products \\
\hline Features clarity & Students and specialist only & Students of secondary schools & All education levels \\
\hline Sampling possibility & No possibility & Only with permission & Unlimited \\
\hline Education diversity & Geological value only & Geological and biotic values & Abiotic, biotic and cultural values \\
\hline \multicolumn{4}{|c|}{ Functional } \\
\hline Capacity & $<10$ persons & $10-20$ persons & $>20$ persons \\
\hline Safety & Threats occur & Taken moderate precautions & No threats \\
\hline Limitations of access & Difficult access & Seasonally access difficulties & Good access conditions \\
\hline Distance from paved roads & $>20 \mathrm{~min}$ & 10 to $20 \mathrm{~min}$ & $<10$ min \\
\hline Other education sites & $\begin{array}{l}\text { Lack of others for } 5 \mathrm{~km} \\
\text { radius. }\end{array}$ & $2-3$ sites for $5 \mathrm{~km}$ radius & $>4$ sites for $5 \mathrm{~km}$ radius \\
\hline \multicolumn{4}{|c|}{ Tourists } \\
\hline Scenic values & Lack & Moderate & Interesting vantage point \\
\hline $\begin{array}{l}\text { Location relation to } \\
\text { tourist trails }\end{array}$ & $1 \mathrm{~km}$ from trail & $100 \mathrm{~m}$ to $1 \mathrm{~km}$ from trail & Site located on path \\
\hline Degree of degradation & $\begin{array}{l}\text { High human impact } \\
\text { surrounding }\end{array}$ & $\begin{array}{l}\text { Moderate degree of human } \\
\text { impact }\end{array}$ & No signs of degradation \\
\hline $\begin{array}{l}\text { Distance from tourist } \\
\text { centers }\end{array}$ & $>15 \mathrm{~km}$ & $5-15 \mathrm{~km}$ & $<5 \mathrm{~km}$ away \\
\hline $\begin{array}{l}\text { Accommodation and } \\
\text { Restaurants }\end{array}$ & $>30 \mathrm{~km}$ away & 10-20km away & $<10 \mathrm{~km}$ \\
\hline
\end{tabular}


Table 4. The categorise weighting values of different audience and the resulting ranking intervals (modified from Gajeck et al., 201

\begin{tabular}{|c|c|c|c|c|c|c|c|c|}
\hline \multirow{2}{*}{$\begin{array}{c}\text { Quarry } \\
\text { No. }\end{array}$} & \multicolumn{5}{|c|}{ Audience values } & \multicolumn{3}{c|}{ Audience values } \\
\cline { 2 - 9 } & $\begin{array}{c}\text { Scientific } \\
(\mathbf{1 0} \text { pt.) }\end{array}$ & $\begin{array}{c}\text { Educational } \\
(\mathbf{1 0} \text { pt.) }\end{array}$ & $\begin{array}{c}\text { Functional } \\
(\mathbf{1 0} \mathbf{~ p t .})\end{array}$ & $\begin{array}{c}\text { Touristic } \\
\mathbf{( 1 0} \mathbf{~ p t . )}\end{array}$ & $\begin{array}{c}\text { Total } \\
\mathbf{( 4 0 ~ P t )}\end{array}$ & $\begin{array}{c}\text { University } \\
\text { Students }\end{array}$ & $\begin{array}{c}\text { School } \\
\text { Pupils }\end{array}$ & Tourists \\
\hline Q1 & 6 & 8 & 9 & 5 & 28 & 38 & 40.5 & 37.5 \\
\hline Q2 & 8 & 8 & 6 & 3 & 25 & 37 & 36 & 32 \\
\hline Q3 & 8 & 7 & 6 & 3 & 24 & 35.5 & 34 & 30 \\
\hline Q4 & 10 & 10 & 9 & 6 & 35 & 50 & 49.5 & 45.5 \\
\hline Q5 & 10 & 10 & 7 & 6 & 33 & 48 & 46.5 & 42.5 \\
\hline Q6 & 10 & 10 & 6 & 4 & 30 & 45 & 43 & 37 \\
\hline Q7 & 10 & 8 & 7 & 6 & 31 & 48 & 36.5 & 42.5 \\
\hline Q8 & 9 & 8 & 5 & 5 & 27 & 43 & 41.5 & 36.5 \\
\hline Q9 & 10 & 10 & 6 & 8 & 34 & 49 & 47 & 45 \\
\hline
\end{tabular}

Table 5. The quarries score values of Missan area

\begin{tabular}{|c|c|c|c|c|c|c|c|c|}
\hline \multirow{5}{*}{\multicolumn{4}{|c|}{$\begin{array}{l}\text { Note: } \\
\text { The results of Table (1) are weighted by multiply } \\
\text { by weighting categorise vales (A) and compared } \\
\text { with ranking classes intervals (B). }\end{array}$}} & \multicolumn{5}{|c|}{ Weighting of categorise of values for different audiences } \\
\hline & & & & & Scientific & Educational & Functional & Touristic \\
\hline & & & & $\begin{array}{c}\text { University } \\
\text { students }\end{array}$ & 2 & 1.5 & 1 & 1 \\
\hline & & & & $\begin{array}{l}\text { School } \\
\text { pupils }\end{array}$ & 1 & 2 & 1.5 & 1 \\
\hline & & & & Tourists & 1 & 1 & 1.5 & 2 \\
\hline & B. $\mathbf{R}$ & king classes & rvals fo & fferent cat & ises of value & n audience $\mathbf{r}$ & ed assessmer & \\
\hline & & Categoriz & of values & & & Audien & related asses & ents \\
\hline class & Scientific & Educational & functional & Touristic & Total & School pupils & $\begin{array}{l}\text { University } \\
\text { students }\end{array}$ & Tourists \\
\hline Very low & $2-3.4$ & $1-2.8$ & $3-4.2$ & $0-1.8$ & $12-16.4$ & $16.5-21.9$ & $15.5-21.9$ & $16-22$ \\
\hline Low & $3.41-4.8$ & $2.81-4.6$ & $4.21-5.4$ & $1.81-3.6$ & $16.41-20.8$ & $21.91-27.3$ & $21.91-28.3$ & $22.01-28$ \\
\hline Medium & $4.81-6.2$ & $4.61-6.4$ & $5.41-6.6$ & $3.61-5.4$ & $20.81-25.2$ & $27.31-32.7$ & $28.31-34.7$ & $28.01-34$ \\
\hline High & $6.21-7.6$ & $6.41-8.2$ & $6.61-7.8$ & $5.41-7.2$ & $25.21-29.6$ & $32.71-38.1$ & $34.71-41.1$ & $34.01-40$ \\
\hline Very high & $7.61-9$ & $8.21-10$ & $7.81-9$ & $7.21-9$ & $29.61-34$ & $38.11-43.5$ & $41.11-47.5$ & $40.01-46$ \\
\hline
\end{tabular}

\section{RESULTS}

Final selected quarries assessment is represented in Table 5. Scientific, educational, functional, and touristic scores are computed after many field assessments visits for the quarry's sites. The geoscience available knowledge was taken from masters and doctoral theses and published papers about the study area. The results of each quarry were represented in the same Table. The study area subdivides mainly to six regions, Chlat (Q1), Manzilyea (Q2, Q3), Teeb (Q4, Q5), Band (Q6, Q7), Dwerige (Q8), and Zubidat (Q9) (Table.1). the results of each area are affected by its geological properties like topography, hydrology minerology, and also affected by the occurrence of paved roads and other infrastructure services. 


\section{DISCUSSION}

The final quarries assessment and the results audience types weighting are represented in Table 5. These results are classified according to ranking classes interval (Table 4B) for the purpose of understanding the value of each studied quarry and comparing between them to identify the location weakness points of each one, to work on developing it in the future to be an educational and tourism centre. The scientific and educational score vales are collected together to represent the geoeducation, while Functional and touristic scores together represent the geotourism (Table 6), while, Fig. 6 represents the graphic representation of the Table 6 values. The ranking classification of the study area quarries, (according to Table.4b classes), is shown in Table 7.

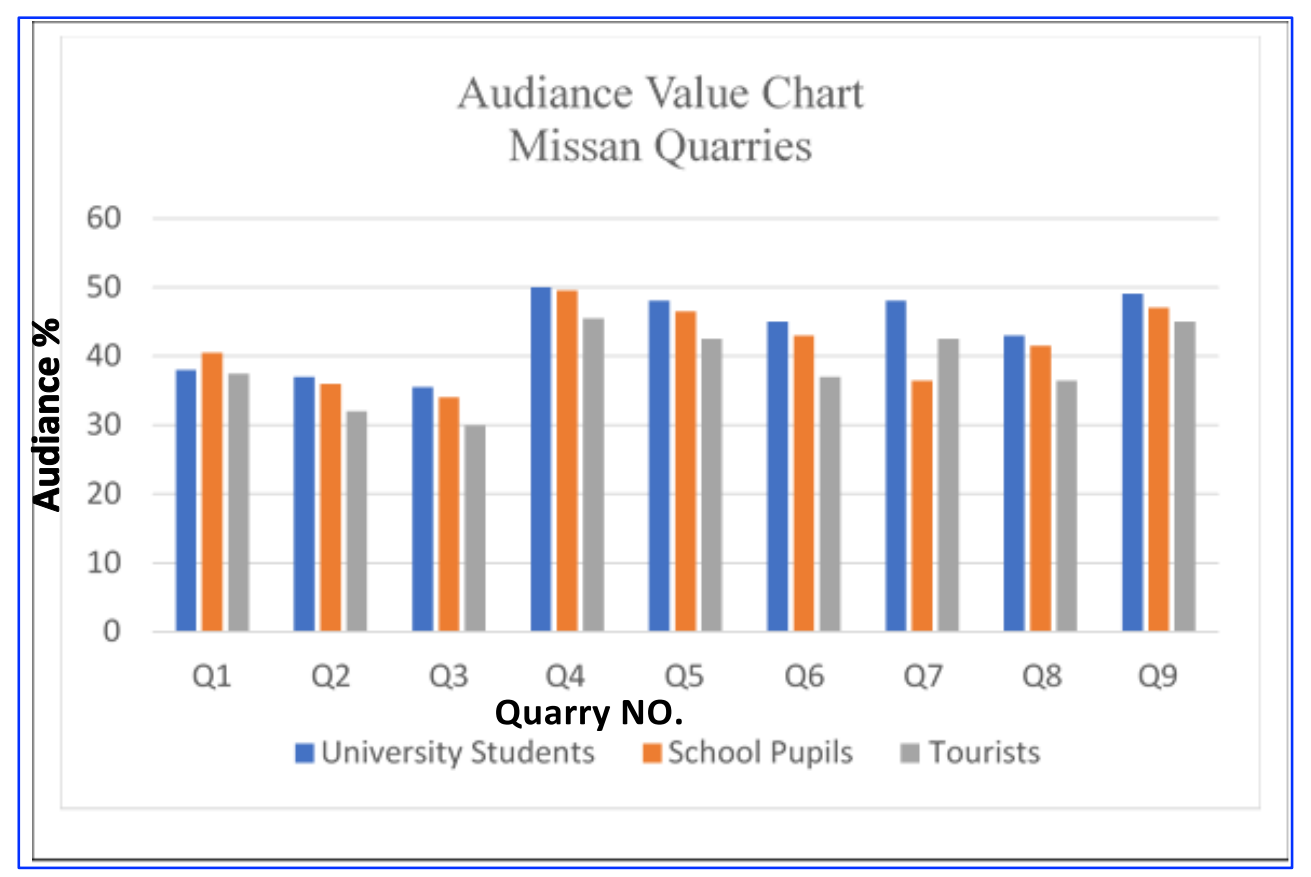

Fig. 6. Audience values of the study selected categorise

Table 6. The quarries geoeducation and geotourism values of east Missan Area

\begin{tabular}{|c|c|c|l|}
\hline Quarry No. & Geoeducation & Geotourism & Geoscience available knowledge \\
\hline Q1 & 14 & 14 & Sdg., Hyd., Mig., Feg,, Gch., Eng. \\
\hline Q2 & 16 & 9 & Min., Stg. Gem., Sdg. \\
\hline Q3 & 15 & 9 & Min., Stg. Gem., Sdg. \\
\hline Q4 & 20 & 15 & Ptg., Eng., Stg., Gmg., Mig., Gch.,Hyd. \\
\hline Q5 & 20 & 13 & Ptg., Eng., Stg., Gmg., Mig., Gch.Hyd. \\
\hline Q6 & 20 & 10 & Ptg., Eng., Stg., Gmg., Mig., Gch.,Hyd, Gmg.,Lig. \\
\hline Q7 & 18 & 13 & Ptg., Eng., Stg., Gmg., Mig., Gch.,Hyd, Gmg.,Lig. \\
\hline Q8 & 17 & 10 & Ptg., Eng., Stg., Gmg., Mig., Gch.Hyd. \\
\hline Q9 & 20 & 14 & Ptg., Eng., Stg., Gmg., Mig., Gch.,Hyd, Gmg.,Lig \\
\hline
\end{tabular}




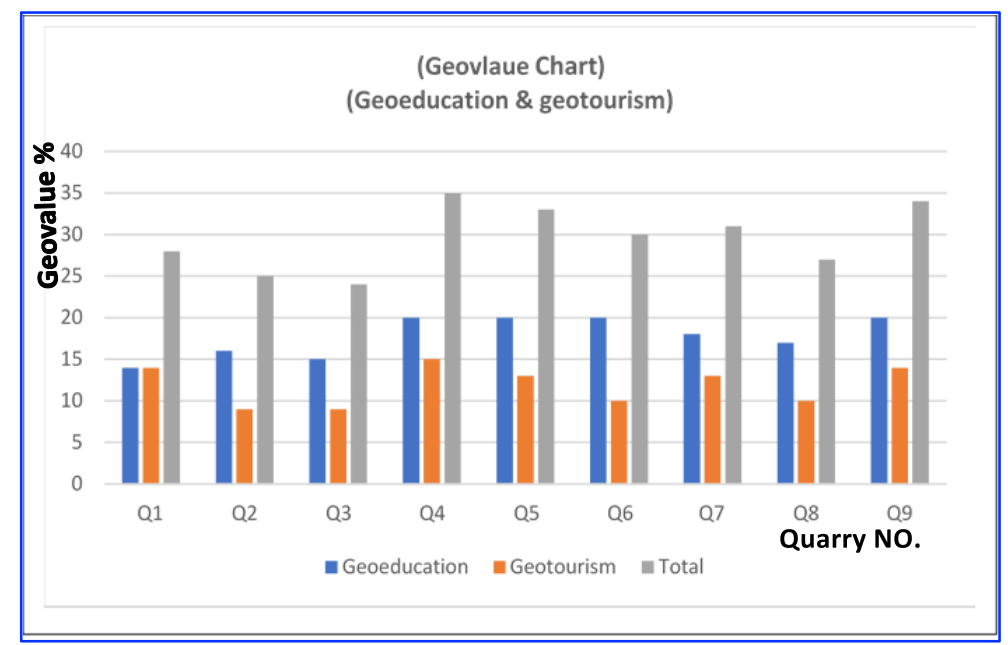

Fig. 7. Geoeducation and geotourism score values of selected quarries

Table 7. The Final quarries assessment of the results categories

\begin{tabular}{|c|c|c|c|c|c|c|c|c|}
\hline Quarry & \multicolumn{5}{|c|}{ Categorise value } & \multicolumn{3}{|c|}{$\begin{array}{c}\text { Audience related } \\
\text { assessment }\end{array}$} \\
\cline { 2 - 9 } & Scientific & Educational & Functional & Touristic & Total & $\begin{array}{c}\text { Univ. } \\
\text { St. }\end{array}$ & $\begin{array}{c}\text { Sch. } \\
\text { Pupils }\end{array}$ & Tourists \\
\hline Q1 & M & H & VH & M & H & H & VH & H \\
\hline Q2 & VH & VH & M & L & M & H & H & M \\
\hline Q3 & VH & H & M & L & M & H & M & M \\
\hline Q4 & VH & VH & VH & H & VH & VH & VH & VH \\
\hline Q5 & VH & VH & H & H & VH & VH & VH & VH \\
\hline Q6 & VH & VH & M & M & VH & VH & VH & H \\
\hline Q7 & VH & VH & H & H & VH & VH & H & VH \\
\hline Q8 & VH & VH & L & M & H & VH & VH & H \\
\hline Q9 & VH & VH & M & M & VH & VH & VH & VH \\
\hline & \multicolumn{7}{|c|}{ L: Low, M: Medium, H: Hight, VH: Very High } & \\
\hline
\end{tabular}

\section{CONCLUSIONS}

The final analysis of quarries assessment represents in the following:

1. Generally, quarries in the study area have a high and a very high assessment scores for geoeducation values (scientific and education) than the geotourism values (functional and tourism).

2. All Quarries are suitable for audience related assessment.

3. Q2 and Q3, (Manzilyea area) are the lowest touristic scores result because their locations are away from the main paved roads as shown in the satellite images.

4. Q4 and Q5 (Teeb area) are the highest values and heights audience assessment because of their proximity to Teeb river and availability of paved roads and bridges. 
5. Q6 and Q7 high geoeducation score value cause the different geological projects in this area like, oil company activities and ground water drilling. This causes increasing in the scientific and educational visitor numbers. Topography of this area is contributed to the attraction of the local families to visit the location many times each year.

6. Q1, Q8 and Q9: are located near the Iraqi Iranian international borderline. These sites have a highly geoeducation and geotourism importance but the infrastructures must develop by local government and community people.

\section{ACKNOWLEDGMENTS}

The authors are very grateful to the Editor in Chief Prof. Dr. Salih M. Awadh, the Secretary of Journal Mr. Samir R. Hijab and the Technical Editor Dr. Heba S. Al-Mimar for their great efforts and valuable comments.

\section{REFERENCES}

Al-Siaede, R. S., 2019. Geotechnical approach to calculate silt volume in Dwerige Weir reservoir by direct surveying methods. Iraqi Geological Journal, 52 (1): 53-60.

Ameen, B. M., 2005. Lithological indicators of Oligocene Gap unconformity at the boundary between high and low folded zones, NE-Iraq. Iraqi Geological Journal, 34-38 (1): 48-56.

Aqrawi, A. A., Goff, J. C., Horbury, A. D., and Sadooni, F. N., 2010. The Petroleum Geology of Iraq. Scientific press.

Awadh. S., M., 2016. Outstanding universal values of the sawa lake as a world natural heritage. Bull. Iraq nat. Hist. Mus. 14 (1): 1-11

Collis, L., and Smith, M. R., 2001. Aggregates: sand, gravel and crushed rock aggregates for construction purposes. Geological Society.

Errami, E., Brocx, M., and Semeniuk, V., 2009. From geoheritage to geoparks. Case studies from Africa and beyond. Bern, Springer.

Gajek, G., Zgłobicki, W., and Kołodyńska-Gawrysiak, R., 2019. Geoeducational value of quarries located within the Małopolska Vistula River Gap (E Poland). Geoheritage, 11(4): 1335-1351.

GEOSURV, 2000. Series of geological maps of Iraq, scale 1:250000. GEOSUR library, Baghdad. Iraq.

Herzog, A., Sales, A., and Hillmer, G., 2008. The UNESCO Araripe Geopark: A Short Story of the Evolution of Life, Rocks and Continents. Expressão Gráfica e Editora.

Henriques, M. H., and Brilha, J. B., 2017. UNESCO Global Geoparks: a Strategy Towards Global Understanding and Sustainability.

Štrba, L., 2015. Identification and evaluation of geosites along existing tourist trail as a primary step of geotourism development: case study from the Spiš region (Slovakia). Geological Journal of Tourism and Geosites, 16(2): 126-140.

Štrba, L., Kolačkovská, J., Kudelas, D., Kršák, B., and Sidor, C., 2020. Geoheritage and geotourism contribution to tourism development in protected areas of Slovakia considerations. Sustainability, 12(7): 2979.

Sinclair, J., 2012. Quarrying opencast and alluvial mining. Springer Science \& Business Media.

Tetik, N., 2016. The importance of interpretation role of tour guides in geotourism: can we called them as geotour guides. International Journal of Education and Social Science, 3(2): 41-53.

Tipton, E., Nickerson, N. P., and Thomsen, J., 2016. Assessing Character of Place to Guide Geotourism-A Case Study of Two Montana Communities.

Tomić, N., and Božić, S., 2014. A modified geosite assessment model (M-GAM) and its application on the Lazar Canyon area (Serbia). International Journal of Environmental Research, 8(4): 1041-1052. 